\title{
Synthesis and Characterization of 1-Ethylamide and 1-Ethanolamide of D-Cloprostenol and their 15-Epimers
}

\author{
CONSTANTIN TANASE ${ }^{1 *}$, DENISA IOANA UDEANU2*, CONSTANTIN DRAGHICl ${ }^{3}$, FLOREA COCU ${ }^{1}$ \\ ${ }^{1}$ National Institute for Chemical -Pharmaceutical Research and Development ICCF, 112 Vitan Av., 031299, Bucharest, Romania \\ ZUniversity of Medicine and Pharmacy Carol Davila, Bucharest, Faculty of Pharmacy, Department of Clinical Laboratory and Food \\ Safety, 6 Traian Vuia, 20956, Bucharest, Romania \\ ${ }^{3}$ Organic Chemistry Center C.D.Nenitescu, 202B Splaiul Independentei, 71141, Bucharest, Romania
}

\begin{abstract}
1-Ethylamide-, 1-ethanolamide of D-Cloprostenol and their 15-epi-isomers were synthesized by amidation of methyl esters of D-Cloprostenol or 15-epi-Cloprostenol. The crude compounds were purified by pressure chromatography on silica gel and fully characterized by $I R,{ }^{1} \mathrm{H}-,{ }^{13} \mathrm{C}-, 2 \mathrm{D}-\mathrm{NMR}$ (COSY and HETCOR) and MS spectroscopy.
\end{abstract}

Keywords: D-Cloprostenol-1-ethylamide, D-Cloprostenol-1-ethanolamide, 15-epi impurities, prostamide, amides, synthesis of amides

Since the discovery of prostaglandins [1] and the characterization and chemical classification of the multitude of structural prostaglandin compounds discovered and synthesized [2], a lot of modifications of the 1-carboxyl group were performed with the goal to reduce the side effects of the acid group and to increase the penetration of the cell wall. The intention was to replace the carboxyl group by a non-ionizable group. The firststep was to replace the carboxyl with an ester. At the beginning, the methyl esters were easily synthesized and the corresponding compounds were investigated [3], but then the isopropyl ester was found later to be the ester most used in the prostaglandin active substances PGF $_{2}$ isopropylester was considered in 1987-1989 to be the most potent ocular hypotensive agent ever reported $[4,5])$, like in (+)- or ( \pm )-Cloprostenol isopropilester, Unoproston isopropylester, Latanoprost, Fluprostenol, Travoprost, Tafluprost, which are mainly used as drugs in the reduction of intraocular pressure. Other transformations were also performed: the reduction of the carboxyl to a primary alcohol $[3,6]$, the replacement of the carboxyl group with a primary or secondary amine $[7,8]$ and the transformation of the carboxyl group with an amide [7-9].

In the amide group there is an increased resonance between the nitrogen and carbonyl group which makes the molecule have some specific characteristic properties. Firstly, the hydrolysis of the amide group is at least two orders of magnitude slower than the hydrolysis of the esters and its hydrolysis in vivo is somewhat similar to what happens in the prodrugs, but not at the same extent. Secondly, the increased resonance between the nitrogen and the carbonyl modifies the $\mathrm{C}-\mathrm{N}$ sigma bond in such a way that the rotation barrier is greater than in the $\mathrm{C}-\mathrm{O}$ group of esters or carboxylic acids. The result is that the prostamide molecule becomes more rigid, more stable in a sterical conformer, which has a significant effect for
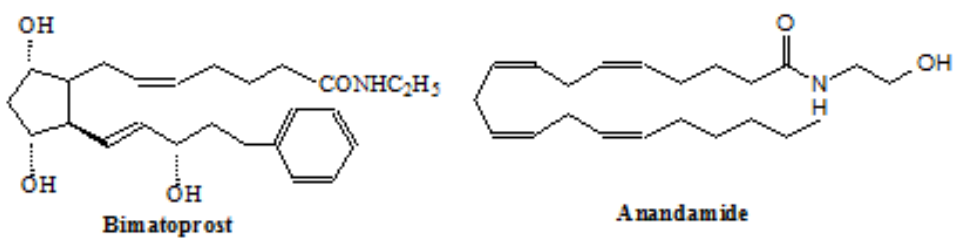

* email: cvtanase@gmail.com; denisaudeanu@gmail.com binding to a number of receptor sites in the pocket geometry. Also, the hydrogen bonding to the receptor sites is changed. All of these changed characteristics confer the prostamides significantly different biological properties than those of prostaglandins.

The progression from the natural prostaglandin amides to the prostaglandin amide analogues was mainly accelerated by two factors:

1. The reduction of the intraocular pressure of the Bimatoprost, a 1-ethylamide analogue of 17-phenyl PGF (fig. 1) [4, 9-11]; this compound has the most efficacious ocular hypotensive activity, greater than that of timolol and Latanoprost [11]. A side effect of the prostaglandins used in reducing the intraocular pressure was efficiently exploited by the use of Bimatoprost not only as a drug, but also as cosmetics for increasing the length, thickness and darkness of eyelashes in patients with hypotrichosis [ 9 , 11-13], and its use in cosmetic products surpassed its use in ocular treatment; this effect was also found and exploited for other isopropyl esters of prostaglandin analogues used for the reduction of ocular pressure, like Latanoprost [13].

2. The discovery of the biological activity of anandamide (ethanolamide of arachidonic acid) as a substrate for cyclooxygenase-2 [14] and generally the elucidation of the biosynthetic pathway from anandamide to the big family of prostamides (fig. 1).

Numerous chemical structures were synthesized [9] and the number of claimed structures is impressive. The research in prostamides is on a raising trend and has extended also to other prostaglandin types, like $\mathrm{PGE}_{2}$ [15].

In the patent literature, amides on a Cloprostenol structure were claimed by someone, butneither the explicit synthesis nor the physico-chemical characterization of amides with an ethyl or ethanol substituent were published. For many years, we have used some amides from

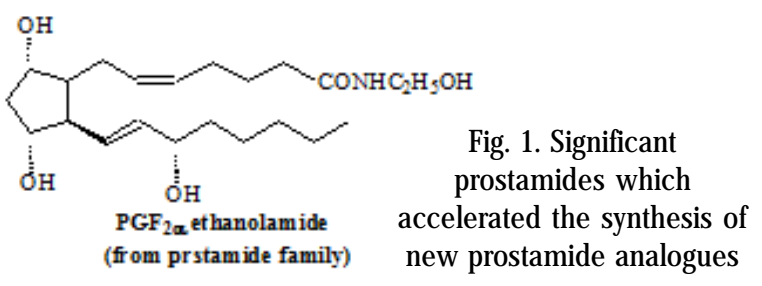


Cloprostenol in different biological evaluations [16]. In this paper we present the synthesis of ethyl and ethanolamides of Cloprostenol and also of their 15-epimer compounds, encountered as impurities in the active substances.

\section{Experimental part}

The starting compounds, D-Cloprostenol methyl ester (1) and epi-D-Cloprostenol methyl ester (4) were obtained at ICCF during the micro-production of prostaglandin analogues. The reagents and solvents were catalogue products and were used as received. The TLC was performed on Merck silica gel glass plates $\mathrm{GF}_{254}$ and developed in the solvent systems mentioned below. The IR spectra were recorded on a FT-IR-100 Perkin Elmer spectrometer, in solid phase by ATR, and frequencies are expressed in $\mathrm{cm}^{-1}$, with the following abbreviations: $\mathrm{w}=$ weak, $\mathrm{m}=$ medium, $\mathrm{s}=$ strong, $\mathrm{v}=$ very, $\mathrm{br}=$ broad. The MS spectra were recorded on a $1200 \mathrm{~L} / \mathrm{MS} / \mathrm{MS}$ triplequadrupole Varian with $\mathrm{ESI}$ interface and fragments given in parenthesis. The ${ }^{1} \mathrm{H}-\mathrm{NMR}$ and ${ }^{13} \mathrm{C}$-NMR spectra were recorded on a Varian Gemini 300 BB spectrometer ( 300 $\mathrm{MHz}$ for ${ }^{1} \mathrm{H}$ and $75 \mathrm{MHz}$ for ${ }^{13} \mathrm{C}$ ) or Bruker $400 \mathrm{MHz}$ (400 $\mathrm{MHz}$ for ${ }^{1} \mathrm{H}$ and $100 \mathrm{MHz}$ for ${ }^{13} \mathrm{C}$ ); the chemical shifts are given in $\mathrm{ppm}$ relative to TMS as internal standard. Complementary spectra: COSY, HETCOR and with trifluoroacetic acid added were done for the correct assignment of the NMR signals. The numbering of the atoms in the compounds is presented in schemes. The purity of the prostamides used in the testing experiments was established by HPLC on a LA CHROM ELITE HITACHI with diode array (DAD) detector on a Kromasil column ( $250 \mathrm{x}$ $4.6 \mathrm{~mm}, \mathrm{C}-18$ silicagel, $5 \mathrm{~mm}$ ), mobile phase: methanolwater-glacial acetic acid, 55:44.3:0.7 (v/v), $1.0 \mathrm{~mL} / \mathrm{min}$., $35^{\circ}, \lambda=275 \mathrm{~nm}$.

\section{Synthesis of the prostaglandin amide analogues}

1. Synthesis of D-Cloprostenol ethylamide, 2

$4.39 \mathrm{~g}$ (10 mmoles) D-Cloprostenol methyl ester were dissolved in $25 \mathrm{~mL}$ methanol, the solution was cooled to $5^{\circ} \mathrm{C}$, then $25 \mathrm{~mL} 30 \%(\mathrm{v} / \mathrm{v})(\sim 115 \mathrm{mM})$ of cooled $\left(5^{\circ} \mathrm{C}\right)$ ethylamine solution in methanol were added and the mixture was stirred at $50^{\circ} \mathrm{C}$ for $72 \mathrm{~h}$ in a pressure flask, while monitoring the reaction by TLC (silica gel, ethyl acetate-methanol-acid acetic, I, 90:13:1, $R_{f 1}=0.63, R_{f 2}=$ $0.45)$. Volatiles were removed under reduced pressure and the residue was purified by pressure chromatography on a silica gel column eluted with dichloromethane, then with the solvent system: dichloromethane-isopropanol in ratios from 98:2 to 95:5. Pure D-Cloprostenol 1-ethyl amide 2 $(3.89 \mathrm{~g}, 86 \%)$ was obtained as an colorless oil, $[\alpha]_{1}=$ $+27.9^{\circ}$ ( $1 \%$ in ethanol), IR: 3298br vs, 2933s, 1631s, 1596vs, $1581 \mathrm{~s}, 1555 \mathrm{~s}, 1480 \mathrm{~s}, 1455 \mathrm{~m}, 1432 \mathrm{~m}, 1286 \mathrm{~s}, 1250 \mathrm{~s}, 1232 \mathrm{~s}$, $1071 \mathrm{~m}, 1032 \mathrm{~s}, 971 \mathrm{w}, 681 \mathrm{w},{ }^{1} \mathrm{H}-\mathrm{NMR}-300 \mathrm{MHz}\left(\mathrm{CDCl}_{2}, \delta\right.$ ppm, J Hz): 7.19 (t, $\left.1 \mathrm{H}, \mathrm{H}-5^{\prime}, 8.2\right), 6.93$ (ddd, $1 \mathrm{H}, \mathrm{H}-4^{\prime}, \mathrm{o}^{\prime} .8$, $1.9,8.2), 6.91$ (t, $\left.1 \mathrm{H}, \mathrm{H}-2^{\prime}, 1.9\right), 6.80$ (ddd, $1 \mathrm{H}, \mathrm{H}-6^{\prime}, 1.1,2.5$, 8.2), $5.73(\mathrm{dd}, 1 \mathrm{H}, \mathrm{H}-13,8.0,15.4), 5.64$ (dd, $1 \mathrm{H}, \mathrm{H}-14,5.8$, 15.4), $5.73(\mathrm{~m}, 1 \mathrm{H}, \mathrm{NH}), 5.41-5.35(\mathrm{~m}, 2 \mathrm{H}, \mathrm{H}-5, \mathrm{H}-6,11.4)$, 4.51 (br dt, $1 \mathrm{H}, \mathrm{H}-15,4.1,7.7), 4.16(\mathrm{t}, 1 \mathrm{H}, \mathrm{H}-9,4.1), 3.96$ ( $m, 1 \mathrm{H}, \mathrm{H}-11), 3.95$ (dd, $1 \mathrm{H}, \mathrm{H}-16,4.1,9.3), 3.90$ (dd, $1 \mathrm{H}, \mathrm{H}-$ $16,7.7,9.3$ ), 3.28 (dd, $\left.1 H, H-1^{\prime \prime}, 5.8,7.4\right), 3.23$ (dd, $1 \mathrm{H}, \mathrm{H}-$ $\left.1^{\prime \prime}, 5.8,7.4\right), 2.37(\mathrm{~m}, 1 \mathrm{H}, \mathrm{H}-12,4.7), 2.34-1.96(\mathrm{~m}, 5 \mathrm{H}, 2 \mathrm{H}-$ 7, 2H-4, 1H-10), 2.15 (t, 2H, H-2, 7.1), 1.79 (d, $1 \mathrm{H}, \mathrm{H}-10$, 14.6), 1.67 (dt, $1 \mathrm{H}, \mathrm{H}-3,6.6,14.0), 1.64(\mathrm{dt}, 1 \mathrm{H}, \mathrm{H}-3,6.9$, 14.0), 1.51 (hept, $1 \mathrm{H}, \mathrm{H}-8,6.0), 1.12\left(\mathrm{t}, 3 \mathrm{H}, \mathrm{CH}_{2}, 7.4\right),{ }^{13} \mathrm{C}$ NMR-75 MHz (CDCl, $\delta$ ppm): $173.38(\mathrm{C}-1), 159.43\left(\mathrm{C}-1^{\prime}\right)$, 135.20 (C-13), $134.98\left(C-3^{\prime}\right), 130.42\left(C-5^{\prime}\right), 129.94$ (C-5 or C-6), 129.75 (C-14), 129.28 (C-6 or C-5), 121.39 (C-4'), $115.20\left(\mathrm{C}-2^{\prime}\right), 113.24\left(\mathrm{C}-6^{\prime}\right), 78.11(\mathrm{C}-11), 72.88(\mathrm{C}-9)$,
72.13 (C-16), 70.82 (C-15), 55.97 (C-12), 50.74 (C-8), 43.09 C-10), 35.93 (C-2), 34.58 (C-1"), 26.78 (C-7), 25.72 (C-4), 25.60 (C-3), 14.95 (C-2"), $\mathrm{C}_{24} \mathrm{H}_{34} \mathrm{CINO}_{5}$, M. wt. 451.983, MS th. $[\mathrm{M}+\mathrm{H}]^{+}:$452.21983, found: $\left[\mathrm{M}+\mathrm{H}^{\prime}\right]^{+}:$452.21976; [434 $\left(\mathrm{C}_{22} \mathrm{H}_{33} \mathrm{ClNO}{ }_{4}\right), 306\left(\mathrm{C}_{18} \mathrm{H}_{28} \mathrm{NO}_{3}\right), 288\left(\mathrm{C}_{18} \mathrm{H}_{26} \mathrm{NO}_{2}\right), 270$ $\left.\left(\mathrm{C}_{18}^{2} \mathrm{H}_{24}^{33} \mathrm{NO}\right)\right]$.

2. Synthesis of epi-D-Cloprostenol ethylamide, 5

The compound was obtained by the same procedure from a fraction of epi-D-Cloprostenol Methyl ester containing 30\% D-Cloprostenol-methyl ester. (silica gel, ethyl acetate-methanol-acid acetic, I, 90:13:1, $R_{f}=0.66$, $\left.R_{f}=0.49\right)$. The product was purified by multiple pressure chromatography on silica gel (eluent: ethyl acetatemethanol, 90:13), resulting a pure fraction of epi-DCloprostenol 1-ethylamide as oil, IR: 3306br vs, 2930s, $2873 \mathrm{~m}, 1642 \mathrm{~s}, 1593 \mathrm{vs}, 1577 \mathrm{~s}, 1557 \mathrm{~s}, 1479 \mathrm{~s}, 1454 \mathrm{~m}$, $1428 \mathrm{~m}, 1284 \mathrm{~m}, 1248 \mathrm{~m}, 1231 \mathrm{~m}, 1070 \mathrm{~m}, 1031 \mathrm{~s}$, 'H-NMR$300 \mathrm{MHz}\left(\mathrm{CDCl}_{3}, \delta \mathrm{ppm}, J \mathrm{~Hz}\right): 7.12\left(\mathrm{t}, 1 \mathrm{H}, \mathrm{H}-5^{\prime}, 8.2\right), 6.86$ (dd, 1H, H-4', 1.9, 8.2), 6.85 (t, 1H, H-2', 1.9), 6.74 (ddd, $1 \mathrm{H}$, $\mathrm{H}-6,1.9,2.2,8.2), 5.82\left(m_{\text {trt }}, 1 \mathrm{H}, \mathrm{NH}\right), 5.66$ (dd, $1 \mathrm{H}, \mathrm{H}-13$, 8.0, 15.4), 5.59 (dd, $1 \mathrm{H}, \mathrm{H}-14 \mathrm{t}, 5.5,15.4), 5.41-5.25$ ( $\mathrm{m}, 2 \mathrm{H}$, $\mathrm{H}-5, \mathrm{H}-6), 4.44$ (br dt, $1 \mathrm{H}, \mathrm{H}-15,4.1,7.0), 4.09$ (brt, 1H, H-9, 4.1), 3.90 (m, 1H, H-11), 3.91 (dd, $1 \mathrm{H}, \mathrm{H}-16,4.1,9.3$ ), 3.83 (dd, $1 \mathrm{H}, \mathrm{H}-16,7.4,9.3), 3.23-3.13\left(\mathrm{~m}, 2 \mathrm{H}, \mathrm{H}-1^{\prime \prime}\right), 2.32(\mathrm{~m}$, $1 \mathrm{H}, \mathrm{H}-12), 2.26-1.96(\mathrm{~m}, 5 \mathrm{H}, 2 \mathrm{H}-7,2 \mathrm{H}-4,1 \mathrm{H}-10), 2.08(\mathrm{t}$, $2 \mathrm{H}, \mathrm{H}-2,7.1), 1.73$ (brd, $1 \mathrm{H}, \mathrm{H}-10,14.0), 1.61$ (dt, $1 \mathrm{H}, \mathrm{H}-3$, $6.6,13.5), 1.56(\mathrm{dt}, 1 \mathrm{H}, \mathrm{H}-3,6.9,13.5), 1.44(\mathrm{~m}, 1 \mathrm{H}, \mathrm{H}-8)$, 1.12 (t, 3H, $\left.\mathrm{CH}_{3}, 7.1\right),{ }^{13} \mathrm{C}-\mathrm{NMR}-75 \mathrm{MHz}\left(\mathrm{CDCl}_{3}, \delta \mathrm{ppm}\right)$ : 173.53 (C-1), 159.46 (C-1'), 134.96 (C-3'), 134.82 (C-13), $130.83\left(C-5^{\prime}\right), 130.40(C-5$ or C-6), 129.89 (C-14), 129.33 (C-6 or C-5), 121.37 (C-4'), 115.24 (C-2'), $113.28\left(C-6^{\prime}\right)$, 78.10 (C-11), 72.87 (C-9), 72.22 (C-16), 70.68 (C-15), 55.93 (C-12), 50.93 (C-8), 43.18 C-10), 35.89 (C-2), $34.60\left(C-1^{\prime \prime}\right)$, 26.75 (C-7), 25.69 (C-4), 25.52 (C-3), 14.87 (C-2").

\section{Synthesis of D-Cloprostenol 1-ethanolamide, 3}

$4.39 \mathrm{~g}$ (10 mmoles) D-Cloprostenol methyl ester were dissolved in $80 \mathrm{~mL}$ methanol, $10 \mathrm{~mL}$ ethanolamine were added, then $16 \mathrm{~mL} 25 \% \mathrm{MeONa}$ in $\mathrm{MeOH}$ ( $70 \mathrm{mM}$ ) solution were added in an argon atmosphere. The mixture was stirred atroom temperature for two days, while monitoring the reaction by TLC (silica gel, I, ethyl acetate-methanolacid acetic, I, 90:13:1, $\left.R_{f 1}=0.63, R_{f 3}=0.25\right)$. The reaction mixture was cooled on an ice-water bath, the base was neutralized with $13 \mathrm{~mL}$ acetic acid and concentrated under reduced pressure. The residue was taken in $70 \mathrm{~mL}$ water and $150 \mathrm{~mL}$ ethyl acetate, the organic phase was separated (aqueous phase was extracted further with $5 \times 75 \mathrm{~mL}$ ethyl acetate), washed with $70 \mathrm{~mL}$ sat. soln. $\mathrm{NaHCO}_{3}, 75 \mathrm{~mL}$ brine, dried $\left(\mathrm{Na}_{2} \mathrm{SO}_{4}\right)$, filtered and concentrated. The crude product was purified by pressure chromatography on silica gel (eluent: dichloromethaneisopropanol, 97:3 to 95:5), resulting $3.70 \mathrm{~g} \mathrm{(79 \% )} \mathrm{pure} \mathrm{D-}$ Cloprostenol ethanolamide 3 as slightly yellow oil, $[\alpha]_{0}=$ $+26.7^{\circ}$ (1\% in ethanol), IR: $3298 \mathrm{br}$ vs, $2929 \mathrm{~s}, 1635 \mathrm{~s}, 1594 \mathrm{~s}$, $1579 \mathrm{~s}, 1553 \mathrm{~m}, 1478 \mathrm{~m}, 1454 \mathrm{~m}, 1429 \mathrm{~m}, 1284 \mathrm{~m}, 1248 \mathrm{~m}$, $1230 \mathrm{~m}, 1068 \mathrm{~m}, 1030 \mathrm{~s}, 969 \mathrm{w}, 679 \mathrm{w},{ }^{1} \mathrm{H}-\mathrm{NMR}-400 \mathrm{MHz}$ (DMSO-d6, d8ppm, J Hz): 7.30 (t, $\left.1 \mathrm{H}, \mathrm{H}-5^{\prime}, 8.4\right) ; 6.98-6.96$ (m, $2 \mathrm{H}, \mathrm{H}-4^{\prime}, \mathrm{H}-2^{\prime}$ ), 6.90 (ddd, $1 \mathrm{H}, \mathrm{H}-6^{\prime}, 1.0,2.5,8.4$ ), 5.56 (dd, $1 \mathrm{H}, \mathrm{H}-13,7.8,15.5)$; 5.50 (dd, $1 \mathrm{H}, \mathrm{H}-14,5.5,15.5) ; 5.41$ (dt, $1 \mathrm{H}, \mathrm{H}-5$ or $6,7.2,10.7$ ), 5.25 (dt, $1 \mathrm{H}, \mathrm{H}-6$ or $5,7.2,10.7$ ), 5.12 (d, 1H, 15-OH, 4.7, deuterable +TFA), 4.63 (br.s, 1H, $\mathrm{CH}_{2} \mathrm{OH}$, deuterable), 4.54 (br $\mathrm{s}, 1 \mathrm{H}, 9-\mathrm{OH}$, deuterable +TFA), 4.38 (d, 1H, 11-OH, 4.1, deuterable +TFA), 4.30 (dt + TFA, $1 \mathrm{H}, \mathrm{H}-15,5.3,6.0)$, 3.91-3.85 (m, 3H, H-9, 2H-16), $3.69(\mathrm{~m}, 1 \mathrm{H}, \mathrm{H}-11), 3.38$ (in water; t, $2 \mathrm{H}, \mathrm{CH}_{2} \mathrm{OH}, 6.0$, with TFA), 3.08 (q, 2H, CH, N, 6.0), 2.20 (ddd, $1 \mathrm{H}, \mathrm{H}-10,6.0,8.8$, 
13.9), 2.16 (dt, $1 \mathrm{H}, \mathrm{H}-12,8.0,11.5), 2.10-2.00(\mathrm{~m}, 2 \mathrm{H}, \mathrm{H}-3$ ), 2.03 (t, $2 \mathrm{H}, \mathrm{H}-2,7.2), 1.94(\mathrm{q}, 2 \mathrm{H}, \mathrm{H}-, 7.2), 1.49$ (qv, $2 \mathrm{H}, \mathrm{H}-4$, 7.2), 1.43 (ddd, $1 \mathrm{H}, \mathrm{H}-10,2.3,5.6,13.9), 1.31$ (ddt, $1 \mathrm{H}, \mathrm{H}-8$, 5.1, 9.8, 11.5), ${ }^{13}$ C-NMR (DMSO-d6, $\delta$ ppm): 172.22 (C-1), $159.64\left(\mathrm{C}-1^{\prime}\right), 133.88\left(\mathrm{C}-3^{\prime}\right), 133.71$ (C-13), 131.02 (C-14), $130.85\left(\mathrm{C}-5^{\prime}\right), 120.47\left(\mathrm{C}-4^{\prime}\right), 114.66\left(\mathrm{C}-2^{\prime}\right), 113.62\left(\mathrm{C}-6^{\prime}\right)$, 79.18 (C-9), 72.47 (C-16), 69.60 (C-15), 69.45 (C-11), 59.97 $\left(\mathrm{CH}_{2} \mathrm{OH}\right), 54.29$ (C-12), 48.81 (C-8), 43.95 (C-10), 41.42 $\left(\mathrm{CH}^{2} \mathrm{NH}\right), 34.93(\mathrm{C}-2), 26.34(\mathrm{C}-7), 25.36(\mathrm{C}-4), 24.80(\mathrm{C}-$ 3). $\mathrm{C}_{22} \mathrm{H}_{3 \mathrm{CINO}}$, M. wt. 467.982, MS th. [M+H] ${ }^{+}: 468.21474$, found: $\left[\mathrm{M}+\mathrm{H}^{\prime}\right]+:$ : 468.21352; [ $450\left(\mathrm{C}_{24} \mathrm{H}_{33} \mathrm{CINO}_{5}\right), 322$ $\left.\left(\mathrm{C}_{18} \mathrm{H}_{28} \mathrm{NO}_{4}\right), 304\left(\mathrm{C}_{18} \mathrm{H}_{26} \mathrm{NO}_{3}\right), 286\left(\mathrm{C}_{18} \mathrm{H}_{24} \mathrm{NO}_{2}\right)\right]$.

4. Synthesis of epi-D-Cloprostenol ethanolamide, 6

The synthesis of epi-D-Cloprostenol ethanolamide, $\mathbf{6}$, was realized in the same way as presented above for $D$ Cloprostenol ethanolamide 3; from $440 \mathrm{mg}$ ( 1 mmole) epiD-Cloprostenol methyl ester, slightly impurified with DCloprostenol methyl ester, $320 \mathrm{mg}(68.4 \%)$ epi-DCloprostenol ethanolamide were obtained as an oil, used in HPLC to identify this impurity in compound 3 ; TLC (silica gel, ethyl acetate-methanol-acetic acid, 90:13:1, $R_{f}$ $\left.=0.66, R_{f}=0.29\right),[\alpha]_{D}=+17.8^{\circ}(1 \%$ in ethanol $), I R$ : 3308 br vs, $2930 \mathrm{~s}, 2875 \mathrm{~m}, 1638 \mathrm{~ms}, 1594 \mathrm{~s}, 1579 \mathrm{~m}, 1552$, $1478 \mathrm{~m}, 1454 \mathrm{~m}, 1430 \mathrm{~m}, 1283 \mathrm{~m}, 1247 \mathrm{~m}, 1230 \mathrm{~m}, 1068 \mathrm{~m}$, 1030s, 974w, 908w, 770w, ${ }^{1} \mathrm{H}-\mathrm{NMR}$ (DMSO-d ${ }_{6}, \mathrm{dppm}^{\mathrm{j}} \mathrm{J} \mathrm{Hz}$ ): 7.29 (t, 1H, H-5', 8.2), 7.00 (t, 1H, H-2', 2.1), 6.97 (ddd, $1 \mathrm{H}$, $\mathrm{H}-4^{\prime}, 0.9,1.9,8.2$ ), 6.91 (ddd, $1 \mathrm{H}, \mathrm{H}-6^{\prime}, 0.9,2.5,8.2$ ), 5.60 (dd, $1 \mathrm{H}, \mathrm{H}-13,7.7,15.6), 5.52$ (dd, $1 \mathrm{H}, \mathrm{H}-14,5.0,15.6), 5.45$ ( $m, 1 \mathrm{H}, \mathrm{H}-5$ or 6$), 5.27$ (dt, $1 \mathrm{H}, \mathrm{H}-6$ or $5,7.1,11.0), 5.15$ (d, $1 \mathrm{H}, 15-\mathrm{OH}, 4.9$, deuterable +TFA), $4.65\left(\mathrm{~m}, 1 \mathrm{H}, \mathrm{CH}_{2} \mathrm{OH}\right)$, $4.55(\mathrm{~d}, 1 \mathrm{H}, 9-\mathrm{OH}, 6.0$, deuterable +TFA), 4.38 (d, 1H, 11$\mathrm{OH}, 5.0$, deuterable +TFA), $4.30(\mathrm{~m}, 1 \mathrm{H}, \mathrm{H}-15), 3.94$ (dd, $1 \mathrm{H}, \mathrm{H}-16,4.1,9.9), 3.90$ (m, $1 \mathrm{H}, \mathrm{H}-9$; dt with TFA, 2.5, 5.8), $3.83(\mathrm{dd}, 1 \mathrm{H}, \mathrm{H}-16,7.1,9.9), 3.68$ (m, 1H, H-11; dt with TFA, 5.8, 8.2), 3.37 (in water; $\mathrm{t}, 2 \mathrm{H}, \mathrm{CH}_{2} \mathrm{OH}, 6.0$, with TFA), 3.09 (q, 2H, CH, N, 6.0$), 2.24-2.13(\mathrm{~m}, 2 \mathrm{H}, \mathrm{H}-10, \mathrm{H}-12), 2.05$ [m (two overlapped triplets), 4H, 2H2, 2H-3, 7.2, 7.7], 1.97 (br q, 2H, H-7, 7.2), with TFA [1.62, t, 1H, H-4, 7.4, with TFA), 1.48 (t, $1 \mathrm{H}, \mathrm{H}-4,7.3$, with TFA)] 1.44 (ddd, $1 \mathrm{H}, \mathrm{H}-10$, HETCOR 2.2, 5.5, 14.0), 1.33 (ddt, with TFA, $1 \mathrm{H}, \mathrm{H}-8,5.0$, $6.3,10.0),{ }^{13}$ C-NMR(DMSO-d $\left.{ }_{6}, \delta p p m\right): 173.82$ (C-1), 160.28 $\left(\mathrm{C}-1^{\prime}\right), 134.31\left(\mathrm{C}-3^{\prime}\right), 134.05^{\prime}(\mathrm{C}-13), 131.44,131.34(2 \mathrm{C}, \mathrm{C}-$ 5, C-6), $130.13\left(\mathrm{C}-5^{\prime}\right), 129.54$ (C-14), 121.05 (C-4'), 115.26 $\left(\mathrm{C}-2^{\prime}\right), 114.27\left(\mathrm{C}-6^{\prime}\right), 76.25$ (C-9), 73.19 (C-16), 70.13 (C15), 69.78 (C-11), 60.57 ( $\left.\mathrm{CH}_{2} \mathrm{OH}\right), 54.81$ (C-12), 49.48 (C8), $44.57(\mathrm{C}-10), 42.03\left(\mathrm{CH}_{2} \mathrm{NH}\right), 35.54(\mathrm{C}-2), 26.97(\mathrm{C}-7)$, 26.00 (C-4), 25.37 (C-3). C C ${ }_{21} \mathrm{H}_{34} \mathrm{CINO}$, M. wt. 467.982, MS th. $[\mathrm{M}+\mathrm{H}]^{+}: 468.21474$, found: $\left[\mathrm{M}+\mathrm{H}^{\prime}\right]^{+}:$: 468.21391; [450 $\left.\left(\mathrm{C}_{24} \mathrm{H}_{33} \mathrm{ClNO}\right)_{5}\right), 322\left(\mathrm{C}_{18} \mathrm{H}_{28} \mathrm{NO}_{4}\right), 304\left(\mathrm{C}_{18} \mathrm{H}_{26} \mathrm{NO}_{3}\right), 286$ $\left.\left(\mathrm{C}_{18}^{24} \mathrm{H}_{24} \mathrm{NO}_{2}\right)\right]$.

The purities of the prostamides were established by HPLC and the retention times were: 26.19 for compound 2, 15.99 for compound $\mathbf{3}$ and 13.67 for compound $\mathbf{6}$. No corresponding epi-5 was detected in HPLC for compound 2 (the purity of the compound was $98.7 \%$ ) and the compound 3 contained $1.6 \%$ epi-impurity 5 and had a 98.2 $\%$ purity; these compounds were used in their conditioning for ocular treatment applications.

\section{Results and discussions}

The synthesis of amides has been extensively studied for obtaining a lot of biologically active compounds ([17] for a recent review) and we have recently applied it for obtaining new oleamide analogues [18]. C-1 unsubstituted prostamides were obtained by treating the corresponding prostaglandin methyl ester with ammonia and $\mathrm{NH}_{4} \mathrm{Cl}$ in a sealed tube [8] and $\mathrm{N}$-alkylamides were obtained by the reaction with primary amines [7], even with aqueous amines like $75 \%$ aqueous EtNH ${ }_{2}$ [19]. Other methods give the amidation of free acid with amines by activation acid with carbonyldiimidazole [15], DCC [20] or chloroformiate [21]. Though the ethylamide or ethanol-amide of Cloprostenol are possibly claimed in some patent, neither the synthesis of these compounds nor their full characterization were presented. For a long time, we have synthesized both of the compounds mentioned above, and these compounds were used in some biological evaluations $[15,16]$. The extensive biological experiments of DCloprostenol 1-ethylamide $\mathbf{2}$ and 1-ethanol-amide $\mathbf{3}$ (Scheme 1) in reducing the intraocular pressure and in dermal treatment like in the case of Bimatoprost and more recently of Latanoprost, require increased quantities of not only of the compounds described above, but also of their 15-epi-counterparts, 5 and 6 (scheme 2). 15-epi-DCloprostenol 1-ethylamide $\mathbf{5}$ and 1-ethanolamide $\mathbf{6}$, are inactive by-products in the active substances $\mathbf{2}$ and $\mathbf{3}$, originated from the total stereoselective synthesis of Cloprostenol at the stage of the stereoselective reduction of the corresponding enone to the allylic alcohol. By the manufacturing regulations, the level of 15-epi impurities was continuously decreased, now being near $1 \%$ in the active compound.

For obtaining the 1-ethylamide compounds, 2 and its 15-epimer $\mathbf{5}$, we have chosen as method the amidation of an ester with an amine. As ester we used D-Cloprostenol methyl ester for obtaining 2, and an impure fraction of 15epi D-Cloprostenol methyl ester (containing near 30\% DCloprostenol methyl ester) for obtaining 5. The amidation was performed in a non-aqueous solvent, with ethylamine in methanol $\left(\left(50^{\circ} \mathrm{C}, 72 \mathrm{~h}\right)\right.$, not with $70 \%$ aq. $\mathrm{EtNH}_{2}$, as mentioned in the literature [4a, 4b], compound 2 being obtained in $\sim 86 \%$ yield. A stream of EtNH $\mathrm{H}_{2}$ was introduced in a methanol solution of the cyclic ester of $\alpha$-side chain with the 9-hydroxyl group (protected at the hydroxyl groups as 11,15 -bis-THP ether) for $3-4 \mathrm{~h}$ at $10^{\circ} \mathrm{C}$, followed by 65$70 \mathrm{~h}$ at $25-30^{\circ} \mathrm{C}$ (no yield data), was also mentioned in a patent for obtaining bimatoprost [4c]. The amidation of the above unprotected cyclic ester of $\alpha$-side chain with the 9-hydroxyl group was performed with 2M EtNH in THF $\left(40^{\circ} \mathrm{C}, 18 \mathrm{~h}, 73.8 \%\right)$ for obtaining bimatoprost [ $\left.4^{2} \mathrm{~d}\right]$. The amidation of D-Cloprostenol isopropylester for obtaining 2 was a very slow reaction, even at elevated temperature.

The amidation of D-Cloprostenol methyl ester 1 with ethanolamine was done in methanol in the presence of sodium methoxide in excess (7:1) as base, at r.t., in over $79 \%$ yield. In the literature, the amidation is presented with a slower excess (1.1:1) of sodium methoxide in nonalcoholic solvent, at reflux with removing the alcohol formed in the reaction [21] and also in a catalyst amount $(5 \% \mathrm{MeONa})$ in almost the same conditions [22]. We have chosen to develop the reaction with an excess of $\mathrm{MeONa}$ in methanol at r.t., the conditions being suitable for the structure of Cloprostenol, which has a chlorine atom linked in meta on the aromatic ring of the molecule.

After the usual work-up, the compounds were purified by pressure chromatography and the pure prostamide analogues were obtained as a colorless or slightly yellow oil, then they were characterized by $[\alpha]_{D}, I R, M S$, $1 \mathrm{H}$ - and ${ }^{13} \mathrm{C}-\mathrm{NMR}$ analysis (Materials and Methods for details). EpiD-Cloprostenol ethylamide $\mathbf{5}$ and epi-D-Cloprostenol ethanolamide $\mathbf{6}$ were synthesized from the epi-Dcloprostenol methyl ester 4 by the same methods presented for compounds $\mathbf{2}$ and $\mathbf{3}$ (scheme 2). Compounds 5 and $\mathbf{6}$ were synthesized to be tested for their activity by comparison with that of $\mathbf{2}$ and $\mathbf{3}$, and also to be used as 
<smiles>CC(=O)CCC/C=C/CC1C(/C=C/C(O)COc2cccc(Cl)c2)C(O)C[C@H]1O</smiles>

D-Cloprostenol m ethyl ester 1
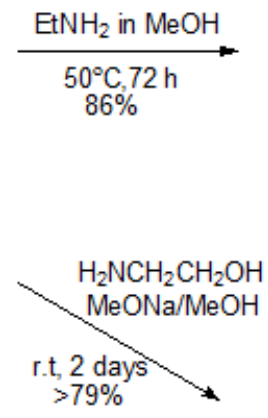

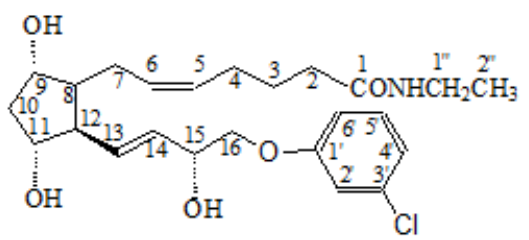

D-Cloprostenol ethylamide 2<smiles>CCC(=O)NCCCC/C=C\CC1C(O)=CC(O)C1/C=C/C(O)COc1cccc(Cl)c1</smiles>

D-Cloprostenol ethanolam ide

3<smiles>CCNC(=O)CCCC=CCC1C(O)CC(O)C1C=C[C@@H](O)COc1cccc(Cl)c1</smiles>

epi-D-Cloprostenol ethylamide

5

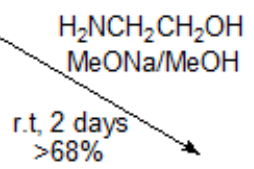

$\mathrm{OH}$

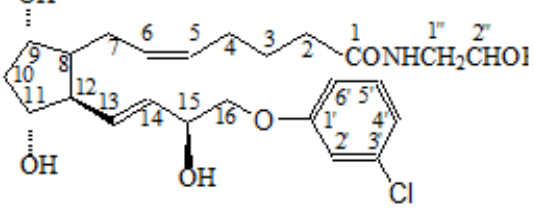

Scheme 1. Synthesis of D-Cloprostenol ethylamide (2) and D-Cloprostenol ethanolamide (3) starting from D-Cloprostenol methyl ester (1)
Scheme 2. Synthesis of epi-D-Cloprostenol ethylamide (5) and epi-D-Cloprostenol ethanolamide (6) starting from epi-D-Cloprostenol methyl ester (4)

epi-D-Clop rostenol ethanolamide

\section{6}

of the pure compounds $\mathbf{2}$ and $\mathbf{3}$, in the active substance and also in the conditioned pharmaceutical drugs.

The purity of the D-Cloprostenol 1-ethyl and 1-ethanol amides was established by HPLC, the compound $\mathbf{2}$ being obtained in $98.7 \%$ and the compound 3 in $98.2 \%$ purity.

\section{Conclusions}

1-Ethyl and 1-ethanolamides of D-Cloprostenol, $\mathbf{2}$ and $\mathbf{3}$, were obtained by the amidation of D-Cloprostenol methyl ester with ethylamide in methanol, respectively with ethanolamide in the presence of sodium methoxide as catalyst. The corresponding 15 -epimers, $\mathbf{5}$ and $\mathbf{6}$, were obtained from an impure fraction of epi-D-Cloprostenol methyl ester (containing 30\% D-cloprostenol methyl ester) by the same procedures as for $\mathbf{2}$ and $\mathbf{3}$. The compounds were purified by pressure chromatography, their purity was determined by HPLC and then they were fully characterized by optical rotation, IR, ${ }^{1} \mathrm{H}-,{ }^{13} \mathrm{C}-, 2 \mathrm{D}-\mathrm{NMR}$, and high resolution MS spectroscopy.

\section{References}

1.Von EULER U. S., Klinische Wochenschrift 14 no 33, 1935, p. $1182-1183$.

2.NELSON, N. A. J. Med. Chem. 17 no 9, 1974, p. 911-8.

3.WOODWARD, D. F., KRAUS, A. H.-P., CHEN, J., GIL, D. W., KEDZIE, K. M., PROTZMAN, C. E., SHI, L., CHEN, R., KRAUS, H. A., BOGARDUS, A. Br. J. Pharmacol. 130, 2000, p. 1933-1943.

4.a) BITO, L. Z. Arch. Ophthalmol. 105, 1987, p. 1036-1039; b) YAO, C.H., YANG, C.-M., CHAO, H.-H., LEE, G.R. US 2009/0259066A1, 15.10.2009; c) WEI, S.-Y., YEH, Y.-C., HSU, M.-K., KAO, L.-T. US 2017/015646 A1, 19.01.2017; d) KARUSALA, N. R., CHAVHAN, B., POTLA, M. K., JERABAJ, R., GOSULA, V., BURMA, P. R., DATTA, D. WO2010/109476 A2, 18.01.2010. 5.SIEBOLD, E. Ocular Surgery News, 59, 1989, p. 3.

6.KLIMKO, P. G., BISHOP, J. E., SALLEE, V. W., ZINKE, P. W. US 6,723, 748 B2, 20.04.2004.

7.BURK, R. M., GARST, M. E., ANDREWS, S. W., WOODWARD, D. F. US 5,352,708, 10.04.1994.

8.WOODWARD, D. F., ANDREWS, S. W., BURK, R. M., GARST, M. E. US $5,688,819,18.11 .1997$.

9.WOODWARD, D. F., BURK, R. M. US 8,648,213 B2, 11.02.2014.

10. WOODWARD, D.F., KRAUSS, A. H., CHEN, J., LIANG, Y., LI, C., PROTZMAN, C. E., BOGARDUS, A., CHEN, R., KEDZIE, K. M., KRAUSS, H. A., GIL, D. W., KHARLAMB, A., WHEELER, L. A., BABUSIS, D., WELTY, D., TANG-LIU, D. D,-S., J. Pharmacol. Exp. Ther. 305, 2003, p. 772-785.

11.WOODWARD, D. F., KRAUSS, A. H.-P., CHEN, J., LAI, R. K., SPADA, C. S., BURK, R. M., ANDREWS, S.W., SHI, L., LIANG, Y., KEDZIE, K. M., CHEN, R., GIL, D. W., KHARLAMB, A., ARCHEAMPONG, A., LING, L., MADHU, C., NI, J ., RIX, P., USANSKY, H., WEBER, A., WELTY, D., YANG, W., TANG-LIU, D. D., GARST, M. E., BRAR, B., WHEELER, L. A., KAPLAN, L. J. Surv Ophthalmol. 45, 2001, p. 337-S345.

12.KHIDHIR, K. G., WOODWARD, D. F., FARIO, N. P., FARIO, B. K., TANG, E. S., WANG, J. W., PICKSLEY, S. M., RANDALL, V. A. FASEB J. 27 no 2, 201

Manuscript received: 13.03 .2018 